\title{
MANAGING OLDER WORKER'S PERFORMANCE: A CHALLENGE FOR POLISH ORGANIZATIONS
}

\author{
${ }^{a}$ Wojciech Ulrych, ${ }^{b}$ Marzena Syper-Jędrzejak \\ ${ }^{a, b}$ University of Łódź, Faculty of Management, Lódź, Poland \\ ae-mail: wulrych@uni.lodz.pl \\ be-mail: marzenasyper@wp.pl
}

\begin{abstract}
Purpose: This paper outlines the present and prospective conditions and practices of managing older employees in Poland from a performance management (PM) viewpoint. It sets out a general framework in this regard. There are very few good examples of how to manage this specific kind of workforce from a system-oriented approach. This is why a comprehensive approach is underlined in this paper.

Methodology: A holistic understanding of managing employee performance is driven by a threestage cycle consisting of planning, supporting and assessing performance. It should be tailored to older worker's needs and be derived from age management assumptions.

Findings: This paper points out that older workers are broadly found to be an underestimated workforce with a set of valuable competencies that can still keep up to date with the modern economy. However, to get more out of the workforce it is a must to join a system-based PM framework with more sophisticated managerial competencies, based on a specific mix of soft and hard skills. There are very few complex findings in the Polish literature in this regard.

Implications for practice: Poland is now at the edge of introducing a new age management approach with employee performance management practices at its core. In the next 25 years it is a must for Polish companies to teach themselves how to manage the older workforce. Managing the staff in question is not just about meeting the age management guidelines, but translating the concept ideas into a real functioning performance-oriented system, to be put into practice between subordinates and their superiors at the lowest level of the organizational hierarchy.

Originality/value: This paper includes proposals and suggestions for practices to be used in managing the performance of older workers, as well as indicating links between employee performance management and different HRM practices. This system-based PM approach is a must to move forward in the twenty first century.
\end{abstract}

Keywords: employee performance management, older workers, age management

Paper type: Conceptual paper 
MANAGING

OLDER WORKER'S

PERFORMANCE

Wojciech Ulrych

Marzena Syper-Jędrzejak

\section{Introduction}

Organizational measures which aim to facilitate the functioning of older people in conditions that guarantee their safety and health include age management. Walker distinguishes 5 reasons why interest in age management systems has recently increased (Walker, 2005):

1) Ageing of workers in European labour market;

2) Low professional activity of elderly people despite the increased share of this age group in the society;

3) Requirements of social policy;

4) Initiatives undertaken by employers;

5) Prevention of discrimination against elderly people in labour market.

According to European Foundation for the Improvement of Living and Working Conditions, age management in enterprises should cover the following areas of activity (Naegele and Walker, 2006; Liwiński and Sztanderska, 2010; Bombiak, 2014):

- recruitment of workers,

- trainings, coaching, continual improvement of staff,

- change in work organization (the use of flexible working hours, adjustment of the shift work system, additional leave, staff turnover),

- promotion and protection of workers health, creating safe working conditions,

- transfer of elderly workers to positions less burdensome,

- programs for completion of work and entering retirement.

Effective programs of age management should be, first of all, systematic and at the same time preventative (Liwiński and Sztanderska, 2010). Preventative measures should be worker-oriented in the whole course of their professional career as well as in all age groups and not just for old workers.

From the methodological viewpoint of this paper, the concept of age management indicates precisely "what" activities should be taken into consideration. We use a widely-accepted and generally-oriented performance management (PM) system which indicates a need for its practices to be translated specifically to meet older worker`s requirements. In other words the PM framework shows a system-oriented approach and indicates "how" to make older worker's productive. This is why we initially present a PM typical model with its practices (Table 1). Next, some theoretical aspects and practical examples of different companies are set out separately for each stage of the PM cycle. Afterwards, wide HRM politics are horizontally connected with the PM model as a complete system. This comprehensive approach to PM is vital in order to not neglect consistent results in terms of organization benefits as well as advantages for the individual. 
2. Older worker's performance management

There is no doubt that age management must meet business model assumptions. We can sometimes see the benefits of having older staff in companies which provide specific products or services connected with age (for example, in the health sector or in the retail trade). An older work service can evoke greater confidence among older customers (Liwiński and Sztanderska, 2010). Performance Management (PM) tailored to older worker`s needs has to derive from age management assumptions. A holistic understanding of managing employee performance is driven by a three-stage cycle consisting of planning, supporting and assessing performance (Armstrong, 2009; Hutchinson, 2013). The PM "good practices" perspective (Table 1) has to be then transformed into a framework of activities done by line managers on an everyday basis. A list of "7 levers of workplace productivity" could be listed as a framework for discussing the question of managing older workers (Beck and Williams, 2016):

1) Well designed work - jobs and work organised in ways that increase efficiency and make the most of people's skills;

2) Skilled managers - managers with the confidence and training to manage and lead effectively;

3) Managing conflict effectively - systems in place to reduce the likelihood of problems arising and to deal with problems at every stage;

4) Clarity about rights and responsibilities - a working environment where everyone understands their rights and responsibilities;

5) Fairness - employees who feel valued and treated fairly;

6) A strong employee voice - informed employees who can contribute and who are listened to;

7) Trust - relationships based on trust, with employers sharing information at the earliest opportunity.

\begin{tabular}{lll}
\hline & & - Define role profiles, updating as necessary. \\
Start & - Ensure that role profiles set out updated key results areas \\
of & Performance and & and competency requirements. \\
year & development & - Define goals and standards of performance. \\
& agreement & - Identify and define key performance indicators. \\
& & - Draw up performance development plans. \\
& - Draw up personal development plans. \\
\hline \multirow{3}{*}{$\begin{array}{ll}\text { Continuing } \\
\text { dialogue }\end{array}$} & $\begin{array}{l}\text { Managing } \\
\text { performance } \\
\text { throughout } \\
\text { the year }\end{array}$ & $\begin{array}{l}\text { - Monitor progress and review evidence of achievement. } \\
\text { - Provide informal feedback as required. }\end{array}$ \\
\hline
\end{tabular}

Wojciech Ulrych 
MANAGING

OLDER WORKER'S

PERFORMANCE

Wojciech Ulrych

Marzena Syper-Jędrzejak

Table 1.

continued
Prepare for performance review by analyzing achievements (work and learning) against objectives.

Identify specific strengths and weaknesses on the basis of

evidence.

Assess overall performance.

Provide 6feedback.

Use conclusions of performance review as the basis for next year's performance and development agreement.

Below are the stages of the employee performance management cycle presented in terms of managing older worker's needs.

\subsection{Performance and development agreement}

A line manager's responsibility is to adjust the job profile to older worker's competencies. Due to a lower ability in knowledge acquisition, older workers may find it difficult to adapt to changes implemented in their work place as result of new technologies, computerisation, and new equipment. They need more time for learning and the adoption of new skills (Straś-Romanowska, 2014)

Updating role profiles requires attention to the age of the worker, namely hard physical work, work in a hot microclimate and shift work. For example, so far age is not a criterion in formulating requirements for physical work in Poland, however before the employer can authorise the worker to do hard physical work they should conduct a detailed interview taking into account risk factors for heart and cardiovascular diseases and tests confirming their ability to do that kind of work (Kucharska, 2013). Some solutions aimed at the improvement of working conditions for older workers are of a technical nature. They include measures connected with taking into account ergonomics in the construction of the workplace, use of safe equipment (e.g. choosing the right seat, lighting, personal protective equipment and other elements depending on the job) (Rembiasz and Górny, 2015). In the case of older workers it is of particular importance. Work in accordance with ergonomic principles may contribute to longer life and better health of the employees, provided that optimisation of working conditions is a continuous process (designing and modifying work conditions and organization of work). This process ought to ensure safe working conditions enabling intellectual and social (including physical) development of the worker (Górny, 2014).

The following measures should be applied in accordance with the recommendations of the International Labour Organization for older workers (International Labor Organization, 1980; Rembiasz and Górny, 2015):

- reduce burdensome conditions of the working environment,

- change those forms of work organization and working time which lead to stress or overload with the rhythm of work, adapt the workplace 
and tasks to the ability of the worker including the technical means available,

- ensure the systematic monitoring of the health of workers.

The worker of any age, including those who are approaching the retirement age, can be characterised by high labour productivity. A UK worker's ability to do their job still can be maintained even after they hit 65 (Woods, 2011). The condition is to adjust the nature of the work to employee's capabilities, his limitations and predispositions (Rembiasz and Górny, 2015). However, in Poland the vast majority ( 8 out of 10) of Polish workers believe that people aged $50+$ have lower predispositions to acquire new skills than young people. Another $42 \%$ think that people aged 55+ are less productive at work than younger generation (Instytut Badawczy Randstad, 2015).

\subsection{Managing performance throughout the year}

Supporting employee performance boils down to a set of activities fulfilled by a line manager. It consists in monitoring, giving feedback, coaching and mentoring. People aged 60 and more work best when they are not under the pressure of time and can perform their tasks at their own pace. It is worth taking it into consideration when working or supervising work of people at more advanced age (Trempała, 2014; Straś-Romanowska, 2014). Moreover, in work environment, the older worker apart from his precision and conscientiousness can offer something even more valuable from the point of view of the organization - experience and developed over the years ways of dealing with professional problems. Hence, creating mix-age teams provides opportunity for intergenerational transfer of knowledge and skills and thus for maintaining continuity of knowledge and skill resources in staff teams (Liwiński and Sztanderska, 2010). Also, workers in mid and late adulthood can be offered a function of a mentor or a teacher of young staff - this creates an opportunity to increase the sense of appreciation in mentors and at the same time to reliably educate young people hired for work. Possible for application is here inter-mentoring which is a modified version of traditional mentoring, i.e. introduction of young workers into the principles of functioning of the organization by the older workers. An innovative element is the function of technological mentor - a young worker who trains the older worker in terms of new information technologies, and thus facilitates his adaptation (Bugajska et al., 2010).

From the research conducted by Central Institute for Labour Protection it transpires that in professions of predominantly intellectual and emotional load, older workers have a sense of greater control at work and better frame of mind than younger workers (Widerszal-Bazyl, 2004). Older workers have slightly different attitude to work than younger workers, which is connected with many factors. First of all, in the course of life they change functions of 
MANAGING OLDER WORKER'S PERFORMANCE

Wojciech Ulrych Marzena Syper-Jędrzejak work as well as related expectations which become more realistic (Thomas and Anderson, 1998). Worldwide research on attitudes to work confirms that for older workers more important is the relation with the employer and coworkers (younger workers derive satisfaction primarily from work they do). The most important factor of engagement of workers aged 35+ is the interest of the management in satisfaction and well-being of the workers (Towers Perrin, 2009).

\subsection{Performance review}

When the employer is aware of the fact that the proportion of older to younger workers is high then current age management practices need come to a decision based on performance criteria. Some older workers are able to keep their jobs on the condition that they have training and development, whereas others are encouraged to take early retirement (Van Dalen et al., 2015). Employers clearly use exit policies more intensively than they use the training and development approach. However, research shows that older workers are very efficient if they do their jobs in accordance with required competencies (Rolland, 2004). It is apparent from a number of well-designed studies that age often has no real influence on performance. Wide individual differences exist and experience often counteracts any age effects (Sparrow, 1986). In almost every dimension of job performance older workers perform better than younger workers. The only possible exception is that older workers are poorer performers at tasks that require solving novel problems without using any sort of aids, e.g. a calculator (Cappelli, 2016). However, age stereotyping can also be observed in performance management based on electronic performance monitoring in the British service sector. Older workers are vulnerable to being labeled as underperformers and in turn this can lead to dismissal (Scholarios and Taylor, 2014).

It should be noted too, that the worker who devoted almost all his life to a specific field or issue, has become an expert in it. The primary characteristic of thinking and acting of experts is automation and, consequently, ability to divide attention, and therefore faster reaction, despite the impact of the ageing process. The worker belonging to this group is usually also able to consider the problem from many perspectives, following intuition developed as a result of years of training. In case of experts we deal with knowledge which is significantly more developed and internally diverse and outside the scope of even the most comprehensive theoretical knowledge in the field. Expertise enables compensation for decline in efficiency (speed, pace) of elementary information processing which is observed in middle age. Compensation for memory deficits is possible due to a different way of organizing information. It is noted that age clearly correlates with the development of expertise systems (Turner and Helms, 1999). 
2.4. Individual performance in HRM politics - rewarding, developing and career development of older workers

There is an understanding in the UK to reward older workers holistically so that it provides them with a tailored total reward package. For example, some older workers may be less interested in financial rewards and more interested in flexible working conditions, extended leave arrangements and an open organisational culture (CIPD, 2008). In Poland it is the employer that benefits from tax incentives when hiring older people. A fair share of older workers (87\%) aged 50-69 receive a base pay. Paying for tasks to be done, commission or any kind of bonus makes only up the minority of the total reward structure. However, workers are mostly pleased with their reward structure but the amount of remuneration leaves much to be desired (Zawadzki, 2009).

According to CIPD report (2011; Woods, 2011) the UK older workers were often neglected when it comes to training and performance management. They had far less formal performance appraisals in comparison to all rest employees (46 to $65 \%$ ratio). It was even worse when to compare training in the last three years ( $51 \%$ to $32 \%$ across all age groups).

British older workers are not subjected to periodic assessment. In Polish companies the situation is similar. Among Polish workers over 45 years of age we can even point out the psychological barriers to learning. They result from the stereotype of a worker reluctant to development and have an impact on the employer's decisions regarding hiring a worker from this age group (Urbaniak, 2008).

There is no clear evidence as to whether career development and training becomes less important for older workers or not (Beck and Williams, 2016). However the CIPD report (2016) saw workers aged over 55 scoring an average of almost 7 out of 10 when ranked on the attributes used to describe a talented employee. Career planning is based on such a distribution of requirements related to work, the applied incentives and burdens throughout the entire period of employment that they will allow the employee to reach sufficiently high level of motivation and capacity to achieve successive degrees of promotion. Career planning should include stage of life and psychophysical conditions of the worker. Older workers should be also informed about possibility of promotion and should be taken into account in training budget (Liwiński and Sztanderska, 2010). Mixage staff teams ensure exchange of experience and division of labour in accordance with abilities (e.g. performing hard physical work by younger people) (Rembiasz and Górny, 2015).

The literature shows that there are many classifications of the stages of a person's professional career along with the characteristics and rules for each stage. Middle age is a period for the highest levels of job satisfaction and usually the most significant achievements (Olejnik, 2014). At the same time, it 
MANAGING OLDER WORKER'S PERFORMANCE

Wojciech Ulrych Marzena Syper-Jędrzejak

Table 2.

An example of a table development tasks of mature man

Source: Own research based on Bańka, 2003; Super, 1957. is a period when there may occur a serious crisis resulting from discrepancies between expectations towards the profession and the actual job performed, and the necessity to redefine the needs, professional goals and general values (Levinson, 1986). The last stage of professional life falls on the period of retirement (postretirement career) and because of its specificity it differs from the period of the middle career (Dubas, 2008; Bohdziewicz, 2008).

In the period of mid adulthood (35-55 years of age) as well as in the period of late adulthood (55+) we can speak about basic development tasks consisting of strengthening and stabilizing the professional career and preparing for retirement (Table 2). Age also changes the professional roles of the worker, starting from a "trainee" through to a "professional", "master" and "counsellor-trainer" and finishing at the age of 65 as a "narrator" (Rembiasz and Górny, 2015).

\begin{tabular}{ll}
\hline Stages of life & Tasks \\
\hline $\begin{array}{l}\text { Mid adul- } \\
\text { thood } \\
\text { 35-55 years } \\
\text { of age }\end{array}$ & $\begin{array}{l}\text { Competition with the younger and protection of own professional position - } \\
\text { sporadic fears of new challenges on the labour market; } \\
\text { Concentration on most important things - specialization in what the individual } \\
\text { does best with the use of accumulated earlier resources; } \\
\text { Developing roles other than professional - social activity deepening sense of } \\
\text { rootedness in the community }\end{array}$ \\
\hline & $\begin{array}{l}\text { Mentoring and being an expert; } \\
\text { In parallel to the professional functioning - development of activity, which will } \\
\text { become a source of further sense of existence after completion of paid work; } \\
\text { Late adul- } \\
\text { thood }\end{array}$ \\
$\begin{array}{l}\text { Continuation of enjoyable tasks - investment of effort in activities which provi- } \\
\text { de most satisfaction; }\end{array}$ \\
$\begin{array}{l}\text { Working on a part-time basis - due to less physical capacity of the body, people } \\
\text { at this stage decide to work fewer hours . }\end{array}$ \\
\hline
\end{tabular}

\section{Conclusions}

The idea of age management is still a new approach in Poland, and the awareness of applied practices in terms of older worker's performance management is still insufficient. Entrepreneurs do not remember of demographic changes which will soon affect the way businesses operate. To a large extent, the competitiveness of enterprises will flow from the effective use of the potential of mature workers. Poland found itself on the $30^{\text {th }}$ place among 34 OECD countries in the ranking of PwC Golden Age Index (2016), assessing the level of utilization of the potential of people aged 55+ in the labour market. Restoring the retirement age of 60 for women and 65 for man is happening at the time when the number of workers aged $55+$ increases in Poland faster than any other age groups (Walewski, 2016).

What is more, among the surveyed Polish managers there is a discrepancy between declared convictions about workers aged 55+ (they are aware of the workers' relevant competences) and actions taken towards them (Stankiewicz, 
2015; Bombiak, 2014). Polish employers do not take any measures aimed to encourage the above-mentioned group of workers to stay in the company.

Due to the above reasons we propose the following steps for practitioners to take: firstly, to consider whether this specific group of workers will be an important resource for business models in the nearest future. Secondly, when it comes to managing the staff in question then it is better acquainted with legal and medical requirements. Thirdly, to train and improve an immediate superior`s competencies in terms of older worker's possibilities and constraints. The knowledge of the PM system has to be translated into a set of a company-tailored practices and a wider scope of soft competencies (e.g. empathy) should be welcomed and appraised together with hard competencies. The question of trust between the parties is of the highest importance and only task-oriented management will not be enough to retain older workers and make them productive. A diversity of management styles towards different generations in the same team is a challenge for managers who operate in constantly-changing environments and endless projects to come.

For prospective research in the aforementioned areas a system-oriented PM approach should no doubt be highly investigated in terms of how the bundle of practices work and what effects they produce both for a company as well as its staff. From a PM-centric viewpoint, its dynamics of change in time are the keys to make only fact-based decisions and avoid wishful thinking management. However quantity research in terms of modelling should be supported by quality studies to investigate the data which models derive from.

\section{References}

Armstrong, M. (2009), Performance Management: key strategies and practical quidelines, Kogan, London.

Bańka, A. (2003), Zawodoznawstwo, Doradztwo zawodowe, Pośrednictwo pracy: Psychologiczne Metody i Strategie Pomocy Bezrobotnym, Print-B, Poznań.

Beck, V., Williams, G. (2016), "Managing Older Workers: A report for Acas", available at: http://www.acas.org.uk/media/pdf/f/i/Managing-older-workers-a-report-for-acas. pdf (accessed 4 February 2017).

Bohdziewicz, P. (2008), Kariery zawodowe w gospodarce opartej na wiedzy, Wydawnictwo Uniwersytetu Łódzkiego, Łódź.

Bombiak, E. (2014), „Zarządzanie różnorodnością - wyzwaniem dla współczesnych menedżerów", Zeszyty Naukowe Uniwersytetu Przyrodniczo-Humanistycznego w Siedlcach, Administracja i Zarzqdzanie, Vol. 102, pp. 109-122.

Bugajska, J., Makowiec-Dąbrowska, T., Wągrowska-Koski, E., (2010). „Zarządzanie wiekiem w przedsiębiorstwach jako element ochrony zdrowia starszych pracowników", Medycyna Pracy, Vol. 61 No. 1, pp. 55-63.

Cappelli, P. (2016), „Managing Older Workers”, Harvard Business Review, available at: https://hbr.org/2010/09/managing-older-workersł (accessed 4 February 2017).

CIPD (2008), ,Managing an aging workforce. The role of total reward”, available at: http://
MANAGING

OLDER WORKER'S

PERFORMANCE

Wojciech Ulrych

Marzena Syper-Jędrzejak 
MANAGING OLDER WORKER'S PERFORMANCE

Wojciech Ulrych Marzena Syper-Jędrzejak
www.cipd.co.uk/NR/rdonlyres/F9A3D839-2E4B-416C-9F8E-76787E2A4D1C/0/ managework.pdf (accessed 17 November 2016).

CIPD (2011), "Focus on managing an ageing workforce. Employee outlook", available at: https://www.cipd.co.uk/Images/employee-outlook_2011-summer-age_tcm18-10854. pdf (accessed 17 November 2016).

CIPD (2016), "Attitudes to employability and talent", available at: https://www.cipd.co.uk/ Images/attitudes-to-employability-and-talent_2016_tcm18-14261.pdf (accessed 17 November 2016).

Dubas, E. (2008), „Kategoria wiekowa 50+. Charakterystyka rozwojowa i aspekty edukacyjne", in: Dubas, E., Pyżalski, J., Muszyński, M. Pavel, J.R. (Eds.), Wspieranie rozwoju bezrobotnych 50+ Doświadczenia projektu Adults Mentoring, Wydawnictwo Uniwersytetu Łódzkiego, Łódź, pp. 19-30.

Górny, A. (2014), "Human Factor and Ergonomics in Essential Requirements for the Operation of Technical Equipment", in: Stephanidis, C. (Ed.), HCI International 2014 - Posters' Extended, HCI International 2014, Greece.

Hutchinson, S. (2013), Performance Management. Theory and Practice, Chartered Institute of Personnel \& Development, London.

Instytut Badawczy Randstad (2015), Monitor rynku pracy, raport z 19. edycji badania. International Labor Organization (1980), Older Workers Recommendation, No. 162.

Kucharska, A. (2013), Pracownik 60+, Główny Inspektorat Pracy, Warszawa.

Levinson, D. (1986), „A conception of adult development”, American Psychologist, Vol. 41 No. 1, pp. 3-13.

Liwiński, J., Sztanderska, U. (2010), Zarzqdzanie wiekiem w przedsiębiorstwie, Warszawa.

Naegele, G., Walker, A. (2006), A Guide to Good Practice in Age Management, European Foundation for the Improvement of Living and Working Foundations, Dublin.

Olejnik, M. (2014), "Średnia dorosłość. Wiek średni”, in: Harwas-Napierała B., Trempała J., (Eds.), Psychologia rozwoju cztowieka. Charakterystyka okresów życia, PWN, Warszawa, pp. 222-262.

PwC (2016), PwC Golden Age Index, available at: https://www.pwc.co.uk/economicservices/assets/pwc-golden-age-index-final.pdf (accessed 4 February 2017).

Rembiasz, M., Górny, A. (2015), „Ergonomia w zarządzaniu wiekiem w przedsiębiorstwie produkcyjnym", Organizacja i Zarzqdzanie, No. 65, pp. 115-126.

Rolland, L. (2004), The Age Chasm: Successfully Managing Age in Your Organisation, Melbourne: Drake White Paper.

Scholarios, D., Taylor, Ph. (2014), "Decommissioned vessels - performance management and older workers in technologically-intensive service work", Technological Forecasting and Social Change, Vol. 89, pp. 333-342. DOI: 10.1016/j.techfore.2014.08.004

Sparrow, P.R. (1986), "Job performance among older workers", Ageing International, Vol. 13 No. 4, pp. 5-6. DOI: 10.1007/BF03024740

Stankiewicz, K. (2015), „Niezgodność przekonań i działań menedżerów wobec pracowników w wieku 55+”, Edukacja ekonomistów i menedżerów, Vol. 1 No. 35, pp. 95-107.

Straś-Romanowska, M. (2014), „Późna dorosłość. Wiek starzenia się”, in: HarwasNapierała, B., Trempała, J. (Eds.), Psychologia rozwoju człowieka. Charakterystyka okresów życia, PWN, Warszawa, pp. 263-292. 
Super, D. (1957), The Psychology of Careers, New York: Harper and Row.

Thomas, H., Anderson, N. (1998), "Changes in newcomers' psychological contracts during organizational socialization: A study of recruits entering the British Army", Journal of Organizational Behavior, Vol. 19, pp. 745-767.

Towers Perrin (2009), "Closing the Engagement Gap: A Road Map for Driving Superior Business Performance", Towers Perrin Global Workforce Study 2007-2008, available at: https://c.ymcdn.com/sites/simnet.site-ym.com/resource/ group/066D79D1-E2A8-4AB5-B621-60E58640FF7B/leadership_workshop_2010/ towers_perrin_global_workfor.pdf (accessed 16 January 2017).

Trempała, J. (2014), „Ageizm a funkcjonowanie i rozwój ludzi starszych”, WarmińskoMazurski Kwartalnik Naukowy, Vol. 1 No. 9, pp. 9-22.

Turner, J., Helms, D. (1999), Rozwój człowieka, PWN, Warszawa.

Urbaniak, B. (2008), „Wyzwania wobec edukacji starszych pracowników w Polsce”, in. Kowaleski, J.T., Szukalski, P. (Eds.), Pomyślne starzenie się w perspektywie nauk o pracy i polityce społecznej, Łódź: Wydawnictwo Uniwersytetu Łódzkiego, pp. 68-83.

Van Dalen, H., Henkens, K., Wang, M. (2015), „Recharging or retiring older workers? uncovering the age-based strategies of European employers", The Gerontologist, Vol. 55 No. 5, pp. 814-824. DOI:10.1093/geront/gnu048

Walewski, M. (2016), "Niewykorzystany potencjał starszych pracowników", Harvard Business Review, available at: 163 https://www.hbrp.pl/a/niewykorzystany-potencjalstarszych-pracownikow/1BZ1g3YyK (accessed 4 February 2017).

Walker, A. (2005), "Emergency of age management in Europe", International Journal of Organisational Behaviour, Vol. 10, pp. 685-697.

Widerszal-Bazyl, M. (2004), Stres psychospołeczny wśród pracowników w starszym wieku, CIOP-PIB, Warszawa.

Woods, D. (2011), „Age discrimination? Older workers still neglected over training and performance issues", CIPD findings, available at: http://www.hrmagazine.co.uk/ article-details/age-discrimination-older-workers-still-neglected-over-training-and -performance-issues-cipd-finds (accessed 4 February 2017).

Zawadzki, K. (2009), „Formy wynagrodzeń i aktywność zawodowa osób starszych”, in: Wiśniewski Z. (Ed.), Zarządzanie wiekiem w organizacjach wobec procesów starzenia się ludności, TNOiK, Toruń, pp. 75-93.
MANAGING

OLDER WORKER'S PERFORMANCE

Wojciech Ulrych

Marzena Syper-Jędrzejak 